\title{
PROTECTING CIVIL LIBERTIES THROUGH FEDERAL COURT INTERVENTION IN ST ATE CRIMINAL MATTERS
}

In Ex parte Young ${ }^{1}$ the Supreme Court created an exception to the doctrine that equity will not interfere in criminal prosecutions ${ }^{2}$ so that federal courts could act to prevent state nullification of federal constitutional rights ${ }^{3}$ by enjoining the enforcement of unconstitutional state laws. $^{4}$ During the 63 years since that decision, the Court has made numerous attempts to achieve a proper balance between the use of this federal equity power and the preservation of the imdependence of the state criminal processes. ${ }^{5}$ Until the Court's decision six years ago in Dombrowski v. Pfister, ${ }^{6}$ the balance adopted rarely allowed intervention. Dombrowski, however, was thought to have removed the traditional limitations and to have made intervention freely available im civil liberties and civil rights cases, perhaps even to the extent that federal courts could use their mjunctive powers to control the substance of state court decisions in these areas and to assure that tactics sucli as court delay would not subvert vindication of these federal rights. $^{7}$ Nevertheless, in a spate of decisions last term-Younger $v$. Harris, ${ }^{8}$ Samuels v. Mackell,${ }^{3}$ Boyle v. Landry, ${ }^{10}$ Perez v. Ledesma, ${ }^{11}$ Dyson v. Stein, ${ }^{12}$ and Byrne v. Karalexis ${ }^{13}$ - the Court made it clear

1. 209 U.S. 123 (1908).

2. See, e.g., In re Sawyer, 124 U.S. 200, 210 (1888).

3. Ex parte Young, 209 U.S. 123 (1908); cf. General Oil Co. v. Crain, 209 U.S. 211, 226-27 (1908).

4. Although Young actually dealt with the power of the lower federal courts to enjoin a state officer from bringing a civil proceeding to compel obedience to a state law, the majority decision attaches no significance to the distinction between civil and criminal state court proceedings. See, e.g., 209 U.S. at 155-56. In a compamion case, Hunter v. Wood, 209 U.S. 205 (1908), the Court applied the Young rationale to a criminal case.

5. Congress has also acted to adjust the scope of federal intervention. See 28 U.S.C. $\S \S 1341,1342,2284(5)$ (1970). None of these measures, however, is usually applicable to a civil liberties intervention suit.

6. 380 U.S. 479 (1965).

7. See, e.g., Brewer, Dombrowski v. Pfister: Federal Injunctions Against State Prosecutions in Civil Rights Cases-A New Trend In Federal-State Judicial Relations, 34 FordHAM L. REv. 71, 95 (1965).
8. 401 U.S. 37 (1971).
9. 401 U.S. 66 (1971).
10. 401 U.S. 77 (1971).
11. 401 U.S. 82 (1971).
12. 401 U.S. 200 (1971) (per curiam).
13. 401 U.S. 216 (1971) (per curiam). 
that Dombrowski did not displace the traditional limitations on federal intervention in state criminal cases, and thus ended the belief that Dombrowski should be interpreted broadly. These recent decisions also made several specific adjustments restricting the use of federal intervention suits and indicated further adjustments that will probably be made in the future. This Comment explores these decisions and the narrowed doctrine of federal intervention they portray.

The Supreme Court's view of American federalisin and two specific court-created doctrines of judicial restraint implementing that view have shaped the rules governing federal court intervention in state criminal matters. The development of these rules is discussed in part I of this Comment. Part III considers the application of these doctrines when injunctions are sought to prevent state officials from using the incidents of the criminal law in bad faith to harass particular defendants. Part III considers their application in cases involving injunctions souglit to prevent the enforcement of state statutes that threaten first amendment rights. The possibility that the federal anti-mjunction statute $^{14}$ may further limit federal court intervention in state criminal matters is explored in part IV.

I

\section{"OUR Federalism"15}

Because in the American federal system both the states and nation liave courts empowered to adjudicate federal matters, the Supreme Court lias felt that, despite its appellate review power over both court systems, conflicts would nevertheless arise if federal courts were not always sensitive to the need for unhampered state courts. ${ }^{10}$ This sensitivity has bred notions of comity; their essence, as the Court recently explained, is "a proper respect for state functions . . . and a continuance of the belief that the National Government will fare best if the States and their institutions are left free to perform their separate functions in their separate ways." ${ }^{17}$ To enforce these notions of comity, the Supreme Court lias created doctrines of restraint that require a federal court to defer to state courts even though botli have jurisdiction.

14. 28 U.S.C. \& 2283 (1970).

15. This is the slogan used by the Court to denominate its theory of federalism. See Younger v. Harris, 401 U.S. 37, $44-45$ (1971).

16. See Younger v. Harris, 401 U.S. 37, $44-45$ (1971); Atlantic Coast Line R.R. v. Brotherhood of Locomotive Eng'rs, 398 U.S. 281, 286 (1970); Stefanelli v. Minard, 342 U.S. 117, 120-21 (1951); Douglas v. City of Jeannette, 319 U.S. 157, 162-63 (1943).

17. Younger v. Harris, 401 U.S. 37, 44 (1971). 


\section{A. Federal Court Deference to State Criminal Courts}

When a state criminal proceeding is involved, the Supreme Court has thought it especially important that notions of comity be respected, because the Constitution leaves the power to enact and enforce criminal codes to the states, and the effective exercise of this power requires the least possible federal interference. ${ }^{18}$ Thus, although the 1871 Civil Rights Act ${ }^{10}$ empowers federal courts to enjoin state prosecutions that violate constitutional rights, ${ }^{20}$ the Supreme Court has held that comity severely restricts the exercise of this power. These suits, the Court has argued, present a great potential for delay that "conscientious counsel might be bound to employ, to subvert the orderly, effective prosecution. . . ."21 They therefore must be avoided whenever possible. ${ }^{22}$

As a result of the Supreme Courts dislike of intervention in state criminal matters, the rule evolved through the course of several early Supreme Court cases dealing with economic rights that a federal court should not interfere in a state prosecution unless the defendant could not adequately protect his rights by defending the state action. ${ }^{23}$ Thus, if a defendant had violated a law, he was not permitted to bring a federal action just to avoid the stigma and burdens involved in asserting his rights in a criminal prosecution. ${ }^{24}$ However, a person who planned future conduct that would violate soine allegedly unconstitutional state statute was allowed to bring a federal intervention suit if he convinced the federal court that he would be subject to unreasonable

18. See Stefanelli v. Minard, 342 U.S. 117, 120-21 (1951).

19. 42 U.S.C. $\$ 1983$ (1970) (originally enacted as Act of April 20, 1871, ch. $22, \S 1,17$ Stat. 13). The statute creates a federal cause of action in equity for redress against anyone who, acting under color of state law, deries another a constitutional right. Jurisdiction exists without inonetary limit pursuant to a statute enacted five years earlier. 28 U.S.C. $\$ 1343$ (3) (1970) (originally enacted as Act of April 9, 1866, ch. 31, $\$ 3,14$ Stat. 27).

20. Douglas v. City of Jeannette, 319 U.S. 157, 161-62 (1943); see Hague v. CrO, 307 U.S. 496 (1939).

21. Stefanelli v. Minard, 342 U.S. 117, 123-24 (1951); see Cameron v. Johnson, 381 U.S. 741, 753-54 (1965) (Black, J., dissenting); cf. City of Greenwood v. Peacock, 384 U.S. 808, 832-33 (1966).

22. Younger v. Harris, 401 U.S. 37, $43-49$ (1971); Cameron v. Johnson, 390 U.S. 611, 623 (1968) (Fortas, J., dissenting); Dounbrowski v. Pfister, 380 U.S. 479, 484-85 (1965); Stefanelli v. Minard, 342 U.S. 117, 120-25 (1951); Douglas v. City of Jeannette, 319 U.S. 157, 162-64 (1943).

The Court has employed a more lenient rule when intervention was sought to challenge a state civil law. See Younger v. Harris, 401 U.S. 37, 47 n.4 (1971); id. at 55 n.2 (Stewart, J., concurring); Wisconsin v. Constantineau, 400 U.S. 433, 437-39 (1971).

23. See, e.g., Willianis v. Miller, 317 U.S. 599, aff'g mem. 48 F. Supp. 277 (N.D. Cal. 1942); Beal v. Missouri Pac. R.R., 312 U.S. 45, $49-51$ (1941); Spielman Motor Sales Co. v. Dodge, 295 U.S. 89, 95-96 (1935); Fenner v. Boykin, 271 U.S. 240, 243-44 (1926). See generally H. Hart \& H. Wechsler, The Federai Courts and the FEDERAL SySTEM 862-64 (1953).

24. See, e.g., Spielman Motor Sales Co. v. Dodge, 295 U.S. 89 (1935). 
burdens if he had to act first and then challenge the statute's constitutionahty in defense of his state prosecution. ${ }^{25}$ The risk of multiple prosecutions, for example, was usually deemed sufficient to justify intervention. $^{26}$ In Douglas v. City of Jeannette ${ }^{27}$ the Court declared this amorphous body of law to be applicable to imtervention cases involving civil liberties, ${ }^{28}$ and in the course of applying the law to the facts of the case, ${ }^{29}$ the Court employed a two-part test that has since become the standard used to decide whether intervention is appropriate: ${ }^{30}$ those seeking federal court aid must show, first, that they have been threatened with some injury other than that incidental to every criminal proceeding brought lawfully and in good faith, and second, that the federal court can afford the petitioners protection not available through prompt trial in the state criminal court and prompt appeal pursued to the Supreme Court. ${ }^{31}$ Federal court intervention therefore cannot be used merely to provide an alternative to the state criminal forum or to eliminate the expense, inconvenience, and anxiety involved in defending any criminal prosecution; ${ }^{32}$ it can be used only when a federal court is able to provide a form of relief necessary to protect the petitioner's rights that the state criminal court is legally powerless to grant. ${ }^{33}$

As the Court recently reemphasized in Perez $v$. Ledesma, ${ }^{34}$ these restrictions on federal court intervention apply to suits indirectly interfering in state criminal cases as well as those directly prohibiting state prosecutions froin continuing. The Perez case involved a federal court order that illegally seized magazines and books be returned to a bookstore. In the last several years lower courts have increasingly issued orders of this type, even when the court involved held that the absence of irreparable ijury precluded enjoining the prosecution based on the illegally seized evidence. ${ }^{35}$ Apparently, despite the Supreme

25. See, e.g., Pierce v. Society of Sisters, 268 U.S. 510 (1925); Terrace v. Thompson, 263 U.S. 197 (1923).

26. See, e.g., Hygrade Provision Co. v. Sherman, 266 U.S. 497, 500 (1925); cf. Beal v. Missouri Pac. R.R., 312 U.S. 45, 50-51 (1941).

27. 319 U.S. 157 (1943).

28. In an earlier civil hberties intervention suit, Hague v. CIO, 307 U.S. 496 (1939), the opinions constituting the majority all assumed that once it is shown that a state law unconstitutionally restricts free expression, a federal court can enjoin its enforcement. Thus, until Douglas it was not certain that the law developed in economic rights intervention cases would be applied to civil liberties cases.

29. The facts are discussed in text accompanying notes 115-16 infra.

30. See, e.g., Younger v. Harris, 401 U.S. 37, 46-47 (1971); Samuels v. Mackell, 401 U.S. 66, 68 (1971); Cameron v. Johnson, 390 U.S 611, 620 (1968); Dombrowski v. Pfister, 380 U.S. 479,485 (1965).

31. 319 U.S. at 164.

32. Younger v. Harris, 401 U.S. 37, 46 (1971).

33. See Douglas v. City of Jeannette, 319 U.S. 157, 164 (1943).

34. 401 U.S. 82 (1971).

35. See, e.g., Tyrone, Inc. v. Wilkenson, 410 F.2d 639 (4th Cir.), cert. denied, 
Court's earlier rejection of a distinction between direct and incidental interference, ${ }^{36}$ the lower courts considered the question of requiring the return of evidence to be so incidental to the criminal prosecution that, even though Douglas prevented direct interference, ordering the return of illegally seized evidence was still proper. In Perez the Supreme Court once again rejected this view, holding that federal intervention cannot ordinarily be used to redress unconstitutional seizures of evidence, ${ }^{37}$ intervention is proper only if the Douglas test is satisfied through a showing of both the danger of irreparable injury ${ }^{38}$ and the inadequacy of the state criminal court's protection. ${ }^{39}$

\section{B. Federal Court Deference to State Civil Courts}

If under the Douglas test it is necessary for a federal court to intervene in a state's criminal processes, the Supreme Court has generally held that a federal court cannot refuse rehief in hopes that a state civil court will grant it. Deferring to a state civil court, the Court has reasoned, fails to give due respect to a suitor's choice to exercise the right granted in the 1871 Civil Rights Act $^{40}$ to invoke the aid of a federal court to protect his federal civil rights from state infringement. ${ }^{41}$ The Court has also recognized that delaying federal action might endanger the free exercise of the very civil rights the petitioner seeks to protect. $^{42}$ There is, lowever, one exception to the general rule that a federal court need not defer to a state civil court-the Pullman-abstention doctrine ${ }^{43}$ - which is applicable when the state practice alleged to be unconstitutional involves unsettled questions of state law that could be resolved by a state court in a inanner that would dis-

396 U.S. 985 (1969).

If, as is usually the case, the only injury is the need to prove in a state criminal court that the evidence was illegally seized and therefore inadmissible, Douglas clearly forbids federal intervention. Dombrowski v. Pfister, 380 U.S. 471, 485 \& n.3 (1965); cf. Stefanelli v. Minard, 342 U.S. 117 (1951).

36. Stefanelli v. Minard, 342 U.S. 117, 123 (1951). Compare Cleary v. Bolger, 371 U.S. 392 (1963) with id. at 411 (Brennan, J., dissenting).

37. 401 U.S. at 85.

38. Id.; Dyson v. Stein, 401 U.S. 200, 203 (1971) (per curiam) (a companion case to Perez).

39. 401 U.S. at 85; Byrne v. Karalexis, 401 U.S. 216, 220 (1971) (per curiam) (a companion case to Perez).

40. 42 U.S.C. $\$ 1983$ (1970). See note 16 supra and accompanying text.

41. Zwickler v. Koota, 389 U.S. 241, 248 (1967).

42. Id. at 252 .

43. See Railroad Comm'n v. Pullman Co., 312 U.S. 496 (1941). There are abstention doctrines other than the Pullman doctrine discussed, but none of them are applicable to civil liberties intervention cases. See generally C. WRIGHT, HANDBOOK OF THE LAW of Federal Courts $\$ 52$ (2d ed. 1970) [hereinafter cited as Wright]; Note, Federal-Question Abstention, 80 HARv. L. REv. 604 (1967). 
pose of the constitutional issue involved. ${ }^{44}$ In that situation the district court retains jurisdiction over the case, but takes no action pending the conclusion of a state action it directs the parties to bring to determine the state issues involved. ${ }^{45}$ If the state court does not resolve the case in favor of the federal petitioner, he may return to the federal court and litigate the federal questions. ${ }^{46}$

Several Supreme Court decisions show that in civil rights and civil liberties cases the Pullman-absention doctrine is applicable only to a limited extent, but it is unclear precisely which cases fall outsidc its scope. Railroad Commission v. Pullman Co., ${ }^{47}$ the fountainhead of the abstention doctrines, itself involved civil rights; black Pullman porters, who had intervened as plaintiffs, claimed that an order of the Texas Railroad Commission indirectly forbidding black einployees from taking charge of Pullman cars violated the equal protection clause. It was precisely because this claim involved an area of such great sensitivity and constitutional importance that the Court felt abstcntion was appropriate. ${ }^{48}$ According to the Court, no constitutional rulings in such areas should be made if the case might be resolved by a definitive state court ruling that state law also prohibited the act. ${ }^{49}$

Overlooking the reliance of the Suprene Court on the civil rights issue in Pullman, Herbert Wechsler later argued that, to avoid the risk of nullification of important federal rights by state processes, abstcntion should not be allowed in civil rights cases. ${ }^{59}$ This argument was adopted by a minority of the Court in Harrison v. $N A A C P,{ }^{51}$ a suit challenging a series of Virginia statutes aimed at outlawing the various activities of the NAACP. ${ }^{52}$ The majority, however, noting that the

44. Pullman-abstention is appropriate only in these "narrowly limited 'special circumstances.' " Zwickler v. Koota, 389 U.S. 241, 248 (1967). A federal court cannot decline to act in a case merely because difficult issues involving the constitutionality of a state law are involved and the state courts have never interpreted the state law, nor simply to give state courts the first opportunity to vindicate federal claims. See Wisconsin v. Constantineau, 400 U.S. 433, 439 (1971); Zwickler v. Koota, supra at 248-51; Harman v. Forssenius, 380 U.S. 528, 534-35 (1965); McNeese v. Board of Educ., 373 U.S. 668,673 n.5 (1963).

45. Railroad Comin'n v. Pullman Co., 312 U.S. 496, 501-02 (1941); see Zwickler v. Koota, 389 U.S. 241, 244 n.4 (1967).

46. England v. Louisiana State Bd. of Medical Examincrs, 375 U.S. 411 (1964). The state court must be advised that the right to return to federal court is being reserved, but the federal issues may be presented to both the state and federal courts. See id. at 421-22.

47. 312 U.S 496 (1941).

48. Id. at 498.

49. Id.

50. Wechsier, Federal Jurisdiction and the Revision of the Judicial Code, 13 LAW \& Contemp. Prob. 216, 230 (1948).

51. 360 U.S. 167 (1959).

52. Id. at 182 (Douglas, J., dissenting). 
state had given the federal court assurances that no attempt would be made to enforce the statutes against the NAACP pending a determination of the statutes' constitutionality in a state civil proceeding, ${ }^{53}$ ordered the district court to abstain. Thus, it was uncertain whether Wechsler's argument had been rejected by the majority; the state's cooperation made it possible for the federal court to abstain without risk that the state would interfere with the NAACP's rights during the delay. Three years later, in McNeese v. Board of Education, ${ }^{54}$ the Court squarely faced the issue of whether a federal court should $a b$ stain when, during the period of abstention, the petitioners would suffer a deprivation of their federal rights. The Court held that because the petitioners, students in a segregated school, were being subjected to an ongoing deprivation of their equal protection rights, abstention was inappropriate. The Court argued that when federal civil rights are presently being infringed by state action, it is immaterial whether the action is legal or illegal as a inatter of state law; ${ }^{55}$ since there is no reason to resolve the state issue, a federal court cannot abstain. Subsequently, in Baggett v. Bullitt, ${ }^{58}$ where the Court feared that the inhibiting effect of a loyalty oath would suppress free expression during the abstention period, ${ }^{57}$ and in Dombrowski $v$. Pfister, ${ }^{58}$ where immediate action was necessary to stop the unconstitutional harassment of the organizing efforts of a civil rights organization, ${ }^{58}$ the Court held that abstention is also improper when first amendment rights would be inpaired by state action pending final adjudication of the issue. Thus, where there is some actual danger of state nullification of civil rights or civil liberties, the Court seems generally to have accepted Wechsler's view that iminediate federal action is appropriate. There are, however, recurring indications in Supreme Court opinions that even in these civil rights and civil liberties cases abstention might be appropriate if a state statute could easily be interpreted so as to avoid the constitutional question. ${ }^{60}$

53. Id. at $178-79$.

54. 373 U.S. 668 (1963).

55. [P]etitioners assert that respondents have been and are depriving them of rights protected by the Fourteenth Amendment. It is immaterial whether respondents' conduct is legal or illegal as a matter of state law. Such claims are entitled to be adjudicated in the federal courts.

Id. at 674 (citations omitted).

56. 377 U.S. 360 (1964).

57. Id. at $378-79$.

58. 380 U.S. 479 (1965).

59. Id. at 489-92. See text accompanying notes 71-75 infra.

60. E.g., Zwickler v. Koota, 389 U.S. 241, 248-49 (1967) (dictum); Dombrowski v. Pfister, 380 U.S. 479, 491 (1965) (dictum). See also Askew v. Hargrave, 401 U.S. 476, $477-78$ (1971) (per curiam); Fornaris v. Ridge Tool Co., 400 U.S. 41 (1971) (per curiam); Reetz v. Bozanich, 397 U.S. 82 (1970). 
II

\section{BAD-FaIth HaRAsSment}

\section{A. The Scope of Bad-Faith Harassment}

One circumstance that federal courts have frequently found to merit intervention is the intentional use of searches, seizures, prosecutions that are baseless or unconstitutionally selective, ${ }^{61}$ or threats of prosecution to harass those exercising first amendment rights. ${ }^{62}$ Local officials have used state police power to interfere with the civil liberties of a diverse group of victims: In the South, civil rights and voter registration campaigns have been frequent victims of harassment. ${ }^{68}$ Other groups that have received protection through federal court intervention are labor organizers, ${ }^{64}$ attorneys representing unpopular clients, ${ }^{66}$ newsinen making unfavorable reports concerning local governmental actions, ${ }^{86}$ newspapers, ${ }^{67}$ and "hippies."

At the extreme, harassnient may involve patently illegal police conduct. In Hague v. $\mathrm{ClO}^{69}$ for example, the police suppressed the union's organizing efforts by seizing and destroying union literature, mterrupting union neetings, ${ }^{70}$ and forcibly deporting union organizers. Because such obvious official lawlessness is so easily proved to be something other than a legitimate effort to enforce state law, the Supreme Court did not hesitate to sanction intervention.

The need to rely on acts that are part of an allegedly valid law enforcement effort, however, has not hindered those wishing to use

61. Prosecutions are unconstitutionally selective when state officials intentionally administer unequally a law fair on its face. See Snowden v. Hughes, 321 U.S. 1,8 (1944); Yick Wo v. Hopkins, 118 U.S. 356, 362-63 (1886).

62. It is not enough simply to allege that a prosecution has been brought solely for harassment purposes; the harassmeut must be for the purpose of suppressing the free exercise of civil liberties. See Shaw v. Garrison, 293 F. Supp. 937, 950 (E.D. La.), aff'd mem., 393 U.S. 220 (1968).

63. See, e.g., Cameron v. Johnson, 390 U.S. 611 (1968); United States v. McLeod, 385 F.2d 734 (5th Cir. 1967); United States v. Wood, 295 F.2d 772 (5th Cir. 1961), cert. denied, 369 U.S. 850 (1962).

64. See, e.g., Hague v. CIO, 307 U.S. 496 (1939); United Steelworkers v. Bagwell, 383 F.2d 492 (4th Cir. 1967).

65. See, e.g., Sobol v. Perez, 289 F. Supp. 392 (E.D. La. 1968).

66. See, e.g., Sheridan v. Garrison, 415 F.2d 699 (5th Cir. 1969), cert. denicd, 396 U.S. 1040 (1970).

67. See, e.g., Stem v. Batchelor, 300 F. Supp. 602 (N.D. Tex. 1969), vacated per curiam sub nom. Dyson v. Stein, 401 U.S. 200 (1971); Wilhelm v. Turner, 298 F. Supp. 1335 (S.D. Iowa 1969), aff'd, 431 F.2d 177 (8th Cir. 1970), cert. denied, 401 U.S. 947 (1971).

68. See, e.g., Wheeler v. Goodman, 298 F. Supp. 935 (W.D.N.C. 1969), cert. denied, 401 U.S. 987 (1971); Heard v. Rizzo, 281 F. Supp. 720 (E.D. Pa.), aff'd mem., 392 U.S. 646 (1968).

69. 307 U.S. 496 (1939).

70. See Douglas v. City of Jeannette, 319 U.S. 157, 164 (1943). This fact is not clear from the Hague opmions. 
the police power to suppress civil liberties. This was graphically demonstrated in Dombrowski v. Pfister, ${ }^{71}$ where state officials sought to suppress the work of a civil rights organization, the Southern Conference Education Fund (SCEF). ${ }^{72}$ SCEF officers were subjected to repeated attempts by state officials to prosecute them under the state's subversive activities laws despite a state judicial determination that there was no probable cause to believe that the SCEF officials had violated the act. At the same time, state officials made public threats to prosecute members and supporters of SCEF who did not register with the state as supporters of a "subversive organization," thus frightening off many who might have aided SCEF in its work. ${ }^{73}$ Finally, ostensibly using the powers of search and seizure, police raided and ransacked the SCEF officers' homes and offices, and confiscated a truckload of membership and subscription lists, correspondence, and records. Although SCEF was able to get a state judge to suppress the use of this "evidence," his order that the records be returned was stayed pending the outcome of the state's appeal. ${ }^{74}$ This effectively paralyzed SCEF's activities, both because the records were necessary to continue operations and because knowledge that the records were vulnerable to public scrutiny deterred the organization's efforts to find supporters for its locally unpopular cause. ${ }^{75}$

71. 380 U.S. 479 (1965).

72. See also International Longshoremen's Union v. Ackerman, 82 F. Supp. 65 (D. Hawaii 1948), rev'd, 187 F.2d 860 (9th Cir.), cert. denied, 342 U.S. 859 (1951) (state officials harassing union organizers by repeatedly making mass arrests, requiring excessive bail, using statutes with severe penalties for prosecuting minor breaches of the peace, and bringing new charges whenever a court released a defendant).

73. As Anthony Amsterdam, a veteran of southern civil rights movement litigation, has discussed, even a single criminal prosecution can be an effective means of discouraging constitutionally protected conduct. Initially, those charged will spend some time, perhaps days or months, in jail under the custody of unsympathetic officials. To secure release, bail must be posted, and when, as in the South, sureties refuse to write bonds for demonstrators, this must be cash bail. Then, although ont of jail, for years the defendants must endure the burden of unresolved criminal charges, and these affect their mobility, acceptance at schools, and ehibility for state benefits such as unemployment compensation. As a result, regardless of the outcome of the prosecution, the defendant and others knowing of his plight realize that, though protected behavior cannot lead to convictions, it can be pumished through harassment by state officials. Thus, their willingness to risk exercise of their federally guaranteed rights is reduced. Amsterdam, Criminal Prosecutions Affecting Federally Guaranteed Civil Rights: Federal Removal and Habeas Corpus Jurisdiction to Abort State Court Trial, 113 U. PA. L. REv. 793, 794-99 (1965). See also Dombrowski v. Pfister, 380 U.S. 479, 486-87 (1965); UNITED States Comm'n on Civil Rights, Law Enforcement: A Report on Equal ProTECTION IN THE SOUTH 68-75 (1965).

74. See Brewer, supra note 7 , at 79.

75. The Court recognized the importance of this chilling effect in its decision that an organization cannot constitutionally be forced to divulge the names of its nembers or supporters absent a compelling state interest. See NAACP v. Alabama ex rel. Patterson, 357 U.S. 449, 460-63 (1958). 


\section{B. Proving Federal Intervention Is Justified}

A federal court will not intervene unless it is convinced that the acts a petitioner complains of are part of a calculated, deliberate effort to use the criminal law to interfere with his civil liberties. This will usually be difficult, because "[o]rdinarily the presumption that the State's motive was law enforcement . . . will carry the day."70 Furthermore, if the petitioner is trying to prove harassment solely by showing that the state prosecution is groundless, he will fail unless there is a total absence of evidence that he violated a state statute ${ }^{77}$-an extremely easy burden of proof for those resisting intervention. ${ }^{78}$ Therefore, although the federal courts have been willing to consider a myriad of factors indicating bad-faith harassment, ${ }^{70}$ it is difficult to present sufficient legally competent evidence to prove it.

A further impediment to intervention under the Douglas rule is the need to demonstrate that irreparable injury will result from a failure to intervene. Several commentators ${ }^{80}$ and some lower federal courts ${ }^{81}$

76. Cameron v. Johnson, 390 U.S. 611, 623 (1968) (Fortas, J., dissenting). In Younger v. Harris, 401 U.S. 37, 49 (1971), a majority of the Court subscribed to this remark.

77. Cameron v. Johnson, 390 U.S. 611, 621-22 (1968).

78. See, e.g., id. at 623-27 (Fortas, J., dissenting).

79. In the past the courts have considered the following recurring factors as possible evidence that the criminal law is being used in bad faith to suppress civil liberties: use of statutes with severe penalties to punish minor offences [see, e.g., IIWU v. Ackerman, 82 F. Supp. 65, 104 (D. Hawaii 1948), rev'd, 187 F.2d 860 (9th Cir.), cert. denied, 342 U.S. 859 (1951) (riot act)]; novel applications of statutes [see, e.g., Wheeler v. Goodman, 298 F. Supp. 935, 940-41 (D.N.C. 1969), cert. denied, 401 U.S. 987 (1971) (vagrancy statute used to arrest person in his own home)]; patently abusive use of search and seizure [see, e.g., Donıbrowski v. Pfister, 380 U.S. 479, 487-88 (1965)]; use of statutes that have been declared unconstitutional [see, e.g., Wells v. Hand, 238 F. Supp. 779, 784 (M.D. Ga.), aff'd mem. sub nom. Wells v. Reynolds, 382 U.S. 39 (1965)]; attempting to prosecute a person under new charges for the same acts involved in a previous prosecution that failed [see, e.g., Cox v. Louisiana, 348 F.2d 750 (5th Cir. 1965), vacated mem., 363 F.2d 877 (5th Cir. 1966)]; and prior actions of state officials indicating animosity [see, e.g., Camibst Films, Inc. v. Illinois, 292 F. Supp. 185, 190 (N.D. Ill. 1968)].

The courts have also apparently been willing to consider and give deference to the United States Attorney General's opinion that harassment is involved, for the Justice Department has been able to sue successfully for intervention when private parties probably would have failed. See, e.g., United States v. McLeod, 385 F.2d 734 (5th Cir. 1967); United States v. Wood, 295 F.2d 772 (5th Cir. 1961), cert. denied, 369 U.S. 850 (1962); Sobol v. Perez, 289 F. Supp. 392 (E.D. La. 1968) (United States as intervenor).

The American Law Institute recommends that federal courts intervene when the evidence shows that "the prosecution is so plainly discriminatory as to anount to a denial of equal protection of the laws." See American LAW INSTITUTE, StUdY of the DiviSION OF JURISDiction BetweEn STate AND Federal CourTs $\$ 1372$ (1969).

80. E.g., AMERICAN LaW INSTTTUTE, supra note 79, comments to \$ 1372; Currie, The Federal Courts and the American Law Institute (pt. 2), 36 U. ChI. L. REv. 268, 329-34 (1969); Comnent, Federal Removal and Injunction to Protect Political Ex- 
have argued that a showing that state officials are using the police power to discourage the exercise of first amendment rights justifies intervention regardless of whether there is adequate protection available through the state criminal courts or irreparable injury is threatened. The Supreme Court, however, apparently has not adopted this view. It has argued that the integrity of the state judicial systems should not be doubted even though the executive officers inay be employing the police power for unconstitutional purposes. ${ }^{82}$ Also, in Dombrowski v. Pfister, ${ }^{83}$ the Court was careful to demonstrate that the particular acts of harassment involved satisfied the Douglas test, and the Court seeined to hold that this was why intervention was proper. ${ }^{84}$ In any case, once bad-faith harassment is proven, showing that there is a danger of imjury sufficient to satisfy the Douglas test will usually be easy. When a state criminal court finds that prosecutorial harassment is involved in a case, it can only dismiss that case. But once local officials intentionally use the police power to harass an unpopular group, it is not unrealistic to assume that they will continue to do so. Thus, the state criminal court cannot provide adequate rehef, and federal intervention is appropriate. If local officials are in fact serious about discontinumg their unconstitutional conduct, they can avoid coercive federal court orders by stipulating to that effect before the federal court. ${ }^{85}$

\section{III}

\section{Statutes That Chill Free Expression}

Because people are generally unwilling to risk criminal punishment to test the constitutionality of statutes regulating free expression merely for the luxury of securing their first amendinent rights, states can use the intimidating effect of the criminal law to compel conduct that they cannot constitutionally require. The Supreme Court has recognized this and has attempted, through the creation of various doctrines, to reduce the risk that criminal convictions will result when

pression and Racial Equality: A Proposed Change, 57 CALF. L. Rev. 694 (1969). But see Wright $\$ 52$, at 208.

81. E.g., Cox v. Louisiana, 348 F.2d 750, 752 (5th Cir. 1965) (Wisdom, J.), vacated mem., 363 F.2d 877 (5th Cir. 1966).

82. See City of Greenwood v. Peacock, 384 U.S. 808, 827-28 (1966).

83. 380 U.S. 479 (1965).

84. Id. at 485-86, 487-89. In his dissent in Perez, one of the Younger series of cases, Justice Brennan explicitly declared that this is the reasoning used in his opinion for the Court in Dombrowski. 401 U.S. at 117-18. In Younger the majority of the Court indicated that it agrees. 401 U.S. at $48-49$.

85. Such a stipulation was made and cited as one fact evidencing good faith in Wells v. Hand, 238 F. Supp. 779 (M.D. Ga.), aff'd mem. sub nom. Wells v. Reynolds, 382 U.S. 39 (1965); cf. Beal v. Missouri Pac. R.R., 312 U.S. 45 (1941) (stipulation to bring a single test case accepted to show that no irreparable injury was threatened). 
statutes restricting free expression rights are tested. ${ }^{88}$ One of the most appealing of these to persons wishing to challenge a statute is testing the statute's constitutionality in a federal intervention action seeking an injunction prohibiting enforcenent of the statute or a declaration of its unconstitutionality.

In early decisions the Court indicated that intervention suits could not be employed to test the constitutionality of state legislation unless a statute was being employed in bad faith to suppress civil liberties ${ }^{87}$ or there was a risk of multiple prosecutions or other factors that made it unreasonable to require that a statute be tested through the criminal courts. ${ }^{88}$ Later, an exception was allowed for the unusual case where a state legislature intentionally sought to employ the chilling effect of a vague statute to suppress constitutionally protected advocacy. ${ }^{80}$ Then, in Dombrowski v. Pfister, ${ }^{90}$ the Court seemed to hold that whenever a vague or overbroad statute clilled free expression and was not susceptible of a rehabilitating construction, the Douglas test is satisfied ${ }^{01}$ and a federal injunction prohibiting enforcement of the statute is appropriate. ${ }^{92}$ There was bad-faith larassment in Dombrowski, ${ }^{93}$ but the Court's argument indicated that even without harassment the chilling effect of a vague or overbroad statute ${ }^{04}$ would be sufficient grounds to justify intervention. ${ }^{95}$

86. See Dombrowski v. Pfister, 380 U.S. 479, 486-87 (1965); Note, The Chilling Effect in Constitutional Law, 69 CoLUM. L. REv. 808, 809-22 (1969).

87. Douglas v. City of Jeannette, 319 U.S. 157, 164-65 (1943) (dictum).

88. See notes 23-26 supra and accompanying text.

89. Gremillion v. United States, 368 U.S. 11, aff'g mem. Bush v. Orleans Parish School Bd., 194 F. Supp. 182 (E.D. La. 1961).

90. 380 U.S. 479 (1965).

91. The Court argued that Douglas allowed intervention in this case because otherwise

the contours of regulation would have to be hammered out case by case-and tested only by those hardy enough to risk criminal prosecution to determine the proper scope of regulation.

380 U.S. at 487 . Even if enough volunteer defendants could be found, free expression would be suppressed while a series of prosecutions were litigated. This would not be an irreparable injury to the petitioner in the traditional sense, but he is allowed to assert the injury that would result to society during the period free expression is impaired. On that basis, it can be said that defense of criminal prosecutions is not adequate protection for the rights involved, and intervention is therefore justified. 380 U.S. at 486-87, 489. See also Perez v. Ledesma, 401 U.S. 82, 118-19 (1971) (Brennan, J., dissenting).

92. 380 U.S. at $485-87$.

93. See text accompanying notes 71-75 supra.

94. The Dombrowski opinion appeared to sanction intervention only in cases involving overbroad statutes [see 380 U.S. at 486], but subsequent cases made it clear that the Court did not intend to distinguish between statutes that chill free expression because of their overbroad sweep and those that chill because of their vagueness. See Perez v. Ledesma, 401 U.S. 82, 119 (1971) (Brennan, J., dissenting); Cameron v. Johnson, 390 U.S. $611,615-16,618$ (1968).

95. 380 U.S. at $485-87,490-91$. Justice Brennan, author of the Dombrowski 


\section{A. Limitations on Intervention to Test Statutes}

Since Dombrowski, the Court has made it clear that two traditional constraints continue to limit the power of federal courts to declare state statutes unconstitutional or enjoin their enforcement. On the one hand, constitutional requirements prevent a court from acting until an actual controversy concerning a statute arises; on the other hand, considerations of comity prevent a federal court from acting once the controversy ripens into an actual prosecution, except in certain extraordinary cases. These restrictions are so inclusive that there remain only a few circumstances in which a federal court can intervene solely to remove the chilling effect of a vague or overbroad state statute.

\section{A Constitutional Case or Controversy}

The Constitution empowers the federal courts to decide only "cases" and "controversies." Therefore, it is only when a statute is challenged within the context of a narrow, specific dispute between parties with adverse legal interests of sufficient immediacy, that a federal court has the constitutional power to judge the validity of state legislation. ${ }^{97}$ While there is some evidence that in enacting the Declaratory Judgment Act $^{98}$ Congress intended for the courts to liberally aid those who otherwise would be forced to risk criminal penalties in order to test the constitutionahity of a statute, ${ }^{90}$ the Court has interpreted the case-orcontroversy requirement as demanding a stricter approach. The Court fears that otherwise the federal courts would assume the power to review the constitutionality of all state legislation, rather than exercising the limited power stemming from Marbury v. Madison ${ }^{100}$ to review legislation that comes before a court as part of a specific controversy. ${ }^{101}$

In the Court's view, the case-or-controversy requirement means that federal courts can grant relief in suits challenging state laws only

opinion, and two other members of the Dombrowski majority have since written decisions declaring that this is the proper interpretation of Dombrowski. See Perez v. Ledesma, 401 U.S. 82, 117-19 (1971) (Brennan, J., dissenting); Cameron v. Johnson, 390 U.S. 611, 622-23 (1968) (Fortas, J., dissenting); Cameron v. Johnson, 381 U.S. 741, 755-56 (1965) (White, J., dissenting). However, Justice Black, who did not participate in the Dombrowski case, dismissed these comments as dicta in his opinion for the Court in Younger. See notes 126-33 infra and accompanying text.

96. U.S. CoNST. art. III, \$ 2. See generally WRIGHT \$ 12 .

97. Younger v. Harris, 401 U.S. 37, 52-53 (1971); Boyle v. Landry, 401 U.S. 77, $80-81$ (1971); Golden v. Zwickler, 394 U.S. 103, 109-10 (1969); Zwickler v. Koota, 389 U.S. 241, 244 n.3 (1967); United Pub. Workers v. Mitchell, 330 U.S. 75, 89-91 (1947); cf. Maryland Cas. Co. v. Pacific Coal \& Oil Co., 312 U.S. 270 (1941).

98. 28 U.S.C. $\$$ 2201-02 (1970).

99. See S. REp. No. 1005, 73d Cong., 2d Sess. 2-3, 6 (1934).

100. 5 U.S. (1 Cranch) 303 (1809).

101. See Younger v. Harris, 401 U.S. 37, $52-53$ (1971); cf. United Pub. Workers v. Mitchell, 330 U.S. 75, 89-91 (1947). 
if the petitioner alleges and proves that he desires to commit specific acts that would violate the statute and that he is afraid to act because of past enforcement practices under the statute or threats of prosecution. ${ }^{102}$ The fear of prosecution cannot be feigned or unreasonable, for "persons having no fears of state prosecution except those that are imaginary or speculative, are not ... appropriate plaintiffs in such cases." 103 In the recent Younger series of cases, the Court repeatedly demonstrated that it will disbelieve declarations that prosecutions are feared, and will decide for itself whether the existence of a statute should reasonably cause fears of prosecution. ${ }^{104}$

The strict rule established by the Supreme Court in these cases ineans that those asserting that a statute inhibits them from engaging in constitutionally protected conduct have the burden of proving the reasonableness of their fears, and this may be difficult. Younger suggests that if the state admits it is likely to prosecute the petitioners, intervention would be appropriate. ${ }^{105}$ Such an admission, however, will be made only in the unusual case when a state wants to resolve questions concerning a statute's constitutionality in a federal intervention suit. Furthermore, even when state officials are willing to cooperate, it is unwise to rely on this type of proof, because the Court once refused to accept a state's declaration that a statute would be enforced. ${ }^{108}$

102. Younger v. Harris, 401 U.S. 37, 42 (1971); Golden v. Zwickler, 394 U.S. 103, 109-10 (1969); United Pub. Workers v. Mitchell, 330 U.S. 75, $89-90$ (1947). But see Epperson v. Arkansas, 393 U.S. 97, 100-02 (1968). See generally 6A J. MOORE, FEDERAL PRACTICE \& 57.12, at 3069-71 (2d ed. 1966).

103. Younger v. Harris, 401 U.S. 37, 42 (1971). The fears must continue to be immediate and reasonable throughout the litigation; if circumstances change before a final judgment is issued, the controversy will be deemed mooted, and dismissed without any judgment on the constitutionality of the statute. See Golden v. Zwickler, 394 U.S. 103,109 (1969) (no longer likely petitioner would defy the statute); Douglas v. City of Jeannette, 319 U.S. 157, 165 (1943) (no longer reasonable to expect prosecutions pursuant to the challenged statute). Because a petitioner must allege a particular course of conduct in order to satisfy the specificity requirement, any delays in reaching a final judgment-such as those involved if a case is appealed to the Supreme Court [see Golden v. Zwickler, supra]-present a great risk that the matter will be mooted and dismissed.

104. In Younger v. Harris, 401 U.S. 37, 41-42 (1971), the Court held that absent specific threats of prosecution neither a college instructor, who taught about revolutionary doctrines, nor members of the Progressive Labor Party, who advocated peaceful change in industrial ownership and political processes, should feel inhibited because another was being prosecuted under a vague criminal syndicalism act for distributing leaflets advocating a change to socialism through peaceful political means. Similarly, in Boyle v. Landry, 401 U.S. 77, 81 (1971), the Court held that a federal court could not intervene to strike down a vague criminal intimidation statute, because no claim was made that any of the plaintiffs, black residents of Chicago, had ever been prosecuted or threatened with prosecution for violating the statute.

105. 401 U.S. at 42.

106. Poe v. Ullman, 367 U.S. 497, 501 (1961) (Frankfurter, J., for the plurality); id. at 509 (Brennan, J., concurring). 


\section{Pending Prosecutions}

The central point of the Supreme Court's recent decisions in Younger v. Harris ${ }^{10 \tau}$ and Samuels v. Mackell ${ }^{108}$ is that, unless certain extraordinary circumstances are involved-bad-faith harassment, for example-a federal court cannot interfere in a pending state prosecution. ${ }^{109}$ In Younger the petitioner sought a federal court injunction staying his state prosecution for violating the California criminal syndicalisin act. He alleged generally that the prosecution imhibited him froin exercising his right of free expression, but he did not show that there was any specific danger of multiple prosecutions or that he was being prosecuted in bad faith. ${ }^{110}$ In these circumstances, the Court held, the Douglas test requires that federal imjunctive relief be denied. The state court would have to determine whether the statute was contitutional on its face before it could convict the petitioner, and this was precisely the issue he wanted to place before the federal court. Furthermore, since the defendant was already being prosecuted, there was no remedy for whatever "chill" occurred before the violation. Thus, the only significant advantage that the federal court could give would have been to spare hin the special burden involved in defending any criminal matter, and this is imsufficient to justify intervention. ${ }^{111}$

In Samuels, where the petitioners were defendants in a pending state prosecution pursuant to New York's criminal anarchy statute, the Court extended the Younger holding to cases where a defendant seeks a declaratory judgment that the statute involved in his pending state prosecution is unconstitutional. ${ }^{112}$ The Court argued that whatever the

107. 401 U.S. 37 (1971).

108. 401 U.S. 66 (1971).

109. The federal action is deemed commenced when the complaint is filed. FED. R. Crv. P. 3. There is, however, no agreement concerning the relevant date for a state action. Dombrowski v. Pfister, 380 U.S. 479, 484 n.2 (1965), held that a state action begun by indictment is not commenced before the grand jury is convened. The lower federal courts disagree about what this means. . Compare Turner v. LaBelle, 251 F. Supp. 443, 446 (D. Conn. 1966) (commences with filing of information) and McSurely v. Ratliff, 282 F. Supp. 848, 853 (E.D. Ky. 1967), appeal dismissed, 390 U.S. 412 (1968) (commences with filing of indictment) with Davis v. Jury Comm'n, 261 F. Supp. 591, 593 (M.D. Ala. 1966) (commences with docketing for presentment to grand jury). Justice Brennan, joined by two other members of the Court, recently declared that the state action should be deemed to commence when it is "filed," apparently meaning when either the information or indictment is filed. Perez v. Ledesma, 401 U.S. 82, 103 (1971) (Brennan, J., dissenting).

110. 401 U.S. at 39,49 . Although the California criminal syndicalism act is nearly identical to the Ohio criminal syndicalism act declared void on its face in Brandenburg v. Ohio, 395 U.S. 444 (1969) (per curiam), no presumption of bad-faith harassment arose from the use of this act to prosecute Harris, because Younger was on appeal to the Supreme Court when Brandenburg was decided.

111. See text accompanying note 32 supra.

112. 401 U.S. at 69. 
legal effect of a declaratory judgment, ${ }^{113}$ as a practical matter, it is likely to have the same disruptive effect on a pending state prosecution as a formal injunction; the limitations on federal injunctions enjoining pending state prosecutions therefore should also apply when declaratory relief is sought. ${ }^{114}$

The pending-prosecution limitation is also relevant in cases where someone other than the state defendant seeks federal relief. In Douglas v. City of Jeannette $e^{115}$ the Court indicated that those in privity with the state defendant are also prohibited from beginning a collateral federal suit to test the statute involved in the state prosecution. ${ }^{116}$ In Douglas a group of Jehovah's Witnesses, claiming to represent all members of that sect, sought to prohibit enforcement of a solicitation ordinance being used to prosecute Jeliovah's Witnesses for selling religious pamphlets. Noting that the criminal court's determination of the ordinance's constitutionality would resolve the matter for the petitioners, the Court suggested that, absent any specific showing that the state criminal cases would not adequately protect the rights of all the Jelovali's Witnesses, a federal court should not intervene. However, apart from these unique circumstances-where the federal petitioners are members of a class that includes the state defendants, and the two groups are engaged in identical conduct-the Court has never suggested that a pending state prosecution for violating a statute would affect a third party seeking federal rehef from the inhibiting effect of the same statute. Nor would this extension be justified; in other circumstances there is no guarantee that a state court decision will be wide enough to include the third parties, so it would be unwise to bar federal relief to unrelated third parties merely because the state action might settle the whole issue. ${ }^{117}$ Furthermore, when the third parties' conduct is not identical, there is no serious, unavoidable risk of interference with pending prosecutions; the federal court need only

113. The Court has never determined what res judicata effect is to be given a declaratory judgment concerning a state crimmal law. The Senate Report on the Declaratory Judgment Act states: "The declaratory judgment is a final, binding judgment between adversary parties and conclusively determines their rights." S. REP. No. 1005, 73d Cong., 2d Sess. 5 (1934). However, there is doubt as to how this general rule applies to a declaratory judgment concerning the constitutionality of a criminal statute. See Samuels v. Mackell, 401 U.S. 66, 72 (1971); Perez v. Ledesma, 401 U.S. 82, 125 (1971) (Brennan, J., dissenting). See generally Currie, The Three-Judge District Court in Constitutional Litigation (pt. 1), 32 U. CHI. L. REv. 1, 16-19 (1964). Some district courts have proceeded on the assumption that their decision will be inerely advisory. See, e.g., Landry v. Daley, 280 F. Supp. 938, 967 (N.D. Ill. 1968), rev'd on other grounds sub nom. Boyle v. Landry, 401 U.S. 77 (1971).

114. 401 U.S. at 72-73.

115. 319 U.S. 157 (1943).

116. Id. at 164-65 (dictum).

117. Cf. Zwickler v, Koota, 389 U.S. 241, 248-52 (1967). 
frame its final decree narrowly so that it is clear no attempt has been made to decide anything but the specific controversy before it. ${ }^{118}$

\section{Exceptions to the Pending-Prosecution Restriction}

In establishing the pending-prosecution restriction, the Younger series of cases makes it clear that certain extraordinary cases are not within the prohibition. The first, and most important, of these is the case in which a vague or overbroad statute is intentionally applied to harass someone exercising free-expression rights. ${ }^{119}$ Under these circumstances, in addition to enjoining the pending prosecution, ${ }^{120}$ the court can consider whether the statutes that were employed to harass the petitioners are constitutional on their face. If the court finds any to be unconstitutionally vague or overbroad, it can enjom state officials from enforcing them until a permissible narrow construction is obtamed by the state in a noncriminal proceeding. ${ }^{121}$ The reason is, while a federal court cannot enjoin the enforcement of a vague or overbroad statute solely because it is susceptible of capricious and discriminatory enforcement, ${ }^{122}$ once state officials use the statute to interfere with constitutional rights it can no longer be assumed that they will respect constitutional prohibitions in their enforcement of the statute. Therefore, it is equitable for a federal court to reinforce the general constitutional prohibitions with a specific injunction despite considerations of comity. ${ }^{123}$

The Younger opinion states that other "extraordinary circumstances" would also justify federal court intervention in a pending state prosecution without bad-faith harassment. ${ }^{124}$ As an example,

118. Of course, a federal court decision that the statute is void on its face will have stare decisis effects beyond the case before the federal court, but this will not affect a pending state case any more than, for example, a decision coming from a sister state. Compare Monica Theater v. Municipal Ct., 9 Cal. App. 3d 1, 16, 88 Cal. Rptr. 71, 81-82 (2d Dist. 1970) with Demich, Inc. v. Ferdon, 426 F.2d 643 (9th Cir. 1970), vacated mem., 401 U.S. 990 (1971).

119. See Younger v. Harris, 401 U.S. 37, 53 (1971).

120. See text accompanying notes 61-85 supra.

121. Dombrowski v. Pfister, 380 U.S. 479, 491 (1965). This does not apply if the statute is susceptible of a narrowing construction that could be established in a single criminal prosecution. Id.

The Younger series of opinions never explicitly declares that this portion of the Dombrowski holding-that further enforcement of a statute once employed in bad faith may be enjoined-continues to be accepted by the Court, but the new opinions do seem to accept it. For example, at one point the Younger opinion discusses enjoining state statutes void on their face as if the rules established in Dombrowski continue to apply. 401 U.S. at 50-51.

122. See text accoinpanying notes 96-106 supra.

123. Sec Younger v. Harris, 401 U.S. 37, $47-49$ (1971); Dombrowski v. Pfister, 380 U.S. $479,485,488-89$ (1965).

124. 401 U.S. at 53 . 
the opinion indicates that intervention would be permissible if the statute involved is

flagrantly and patently violative of express constitutional prohibitions in every clause, sentence and paragraph, and in whatever manner and against whomever an effort might be made to apply it. ${ }^{125}$

Unless the Court intended to discourage the developinent of further exceptions, this is an unfortunate example, for the test that the quote suggests is so severe that it is unlikely ever to be met. Because lower courts are likely to assume that this example was meant to typify the "extraordinary circumstances" that justify intervention in a pending prosecution in the absence of bad-faith harassment, it is likely that lower courts will refuse to create more liberal exceptions. Thus, until the Supreine Court holds that some other specific circumstances warrant this type of relief, federal courts will probably intervene in pending prosecutions only when bad-faith harassment is involved.

\section{Adumbrations of Further Restrictions}

The Court's opinions in Younger ${ }^{126}$ and Samuels ${ }^{127}$ explicitly disavow any intent to express an opinion about when federal courts may intervene if no state criminal prosecution is pending, and a concurring opinion of Justices Stewart and Harlan, two members of the inajority, emphasizes this explicit reservation. ${ }^{128}$ Nevertheless, the Younger opinion strongly suggests that the rule adopted for cases in which federal relief is sought froin pending state criminal prosecutions-that federal intervention is appropriate only in certain extraordinary circumstances-will be extended to cases where federal rehef is sought from future prosecutions. Throughout the opinion, the arguments adduced by the Court for refusing intervention when a prosecution is pending apply equally to cases involving future prosecutions. ${ }^{120}$ Furthermore, the opinion expressly declares that, despite some "unnecessary" statements in Dombrowski indicating that a federal court can intervene whenever vague or overbroad statutes chill free expression, ${ }^{130}$ the present Justices "do not think that opinion stands for the proposition that a federal court can properly enjoin enforcement of a statute solely on the basis of a showing that the statute 'on its face' abridges First Amendment rights." ${ }^{131}$ Rather, the case should be considered

125. Id. at 53-54.

126. 401 U.S. at 41 .

127. 401 U.S. at 73-74.

128. 401 U.S. at 55 (Stewart, J., concurring).

129. Compare Younger v. Harris, 401 U.S. 37, $43-54$ (1971) with Perez v. Ledesma, 401 U.S. 82, 120-21 (1971) (Brennan, J., dissenting).

130. 401 U.S. at 50.

131. Id. at 53. See also id. at 54 . 
solely as an example of intervention because of bad-faith harassment. ${ }^{132}$ Since these statements represented the view of the thenmajority of the Court, ${ }^{133}$ even when no prosecution is pending it may be difficult to justify intervention solely because free expression is being inhibited by vague or overbroad statutes. This will depend upon the views of the Justices appointed to fill the present vacancies on the Court.

Hopefully, the explicit disavowal of settling this point means that, despite the implications of the Younger opinion's argument, the Court will not feel bound to extend the restriction to cases where no prosecution is pending. If the Court were to refuse to permit federal courts to intervene to prevent the chilling effect of vague or overbroad statutes even when no prosecution is pending, the provisions of the first amendinent would be unavailable to those unwilling to risk imprisonment solely to exercise their right of free expression. Unlike the limitations of the case-or-controversy requirement and the Douglas rule-which guarantee that the federal petitioner actually needs to know whether a state law is constitutional and that he is not already involved in litigation likely to determine whether his conduct is constitutionally protected-this limitation would deny federal relief to some who have no alternative but to risk criminal prosecution or forgo their rights. Zwickler v. Koota ${ }^{134}$ illustrates the result this could produce: Zwickler wanted to distribute anonymous handbills opposing the reelection of a Congressinan, ${ }^{135}$ but feared to do so because lie had previously been prosecuted pursuant to a state statute forbidding it. ${ }^{136}$ There were no special factors, such as

132. Id. at $47-50$.

133. This majority consists of the three Justices who unequivocally joined in the opinion of the Court in Younger-Chief Justice Burger, and Justices Black and Blackmun-and the two Justices who joined in the opinion of the Court, but reemphasized the issues expressly not dealt with [see text acconipanying note 128 supra]-Justices Harlan and Stewart. Notably, no member of this majority was one of the five Justices who joined in the opinion of the Court in Dornbrowski-Chief Justice Warren, and Justices Brennan, Douglas, Fortas and White. Of the three members of that majority still on the Court, two-Justices Brennan and White-believe that intervention should be allowed when vague or overbroad statutes chill free expression unless the federal petitioner is a defendant in a pending prosecution. See Perez v. Ledesma, 401 U.S. 82, 120-21 (1971) (Brennan, J., dissenting, jomed by White, J.). The third remaining member of the Dombrowski nuajority-Justice Douglas-also believes intervention should be allowed when vague or overbroad statutes chill free expression; he would even permit intervention in a pending prosecution. See Younger v. Harris, 401 U.S. 37, 59-60 (1971) (Douglas, J., dissenting). Thus, the change in the Court's view concerning intervention to prevent the chilling effect of vague or overbroad statutes was solely the result of the changes that occurred in the Court's composition.

134. 389 U.S. 241 (1967).

135. The right to distribute anonymous handbills was established in Talley v. California, 362 U.S. 60 (1960).

136. The case ended without reaching the constitutional issue when Zwickler's conviction was reversed on state grounds. See Zwickler v. Koota, 261 F. Supp. 985, 987 (E.D.N.Y. 1966), rev'd, 389 U.S. 241 (1967). 
bad-faith harassment, involved, ${ }^{137}$ so, unless intervention were permitted solely on the basis that his first amendment rights were being inhibited, federal relief would be denied. Thus, persons like Zwickler would be faced with the alternative of forgoing their federal right or accepting the burden of an almost certain second prosecution. ${ }^{138}$

A inore appropriate rule would be that absent unusual circumstances a federal court cannot intervene pending the outcome of an existing state trial, but if no state trial has begun, or if it has ended, federal intervention ought to be allowed when a genuine controversy exists. Because of the problems of delay that result from intervention in a pending prosecution ${ }^{\mathbf{1 3 9}}$ and the fact that except in unusual casessuch as those involving bad-faith harassment-requiring abstention does not result in any chilling of civil liberties, ${ }^{140}$ the pending-prosecution limitation is an equitable rule. However, the abstention should only be temporary; once his criminal case in finished, a person should be allowed to bring an intervention suit if his controversy continues. The intervention doctrine was created by the Court in Ex parte Young ${ }^{141}$ because it deemed it appropriate to grant federal relief to petitioners caught in circumstances analogous to those facing persons such as Zwickler, ${ }^{142}$ and it seems as important now as then that federal relief be available for this purpose.

\section{B. Remedies When Intervention Is Proper}

If a federal court finds in a given case that intervention is proper, it must then decide what relief is appropriate. The Supreme Court

137. See id. at $992-93$.

138. Of course, a state might entertain suits to enjoin the enforcement of vague or overbroad statutes even though the Supreme Court held these suits could not be heard in federal courts, but it is unlikely that state courts would do this. They have not even been willing to entertain all those suits that federal courts will hear. Compare Georgia R.R. \& Banking Co. v. Redwine, 342 U.S. 299 (1950) with Musgrove v. Georgia R.R. \& Banking Co., 204 Ga. 139, 49 S.E.2d 26 (1948), appeal dismissed, 335 U.S. 900 (1949). But cf. General Oil Co. v. Crain, 209 U.S. 211 (1908).

139. See text accompanying note 21 supra.

140. This assumes that the Court will allow all the exceptions to the pendingprosecution restriction necessary to assure that civil liberties will not be chilled pending the outcome of the criminal case. It has not yet done this. See text accompanying notes 124-25 supra. For example, the Court has not approved intervention in a pending prosecution when a defendant is engaged in a continuing course of conduct, even though intervention here is necessary to save the defendant from being forced to choose between forgoing the exercise of his rights pending the outcome of the criminal matter or facing the risk that a prosecution will be brought for each time he violates the law in the interim. See text accompanying note 26 supra.

141. 209 U.S. 123 (1908).

142. The plaintiffs in the litigation leading to the Young habeas corpus petition were railroads seeking to enjoin the enforcement of allegedly unconstitutional rate regulations. Because of ruinous penalties, the railroads could not afford to challenge the statutes by disobeying them. See id. at $145-48$. 
tersely explained the rule in Zwicker $v$. Koota: ${ }^{143}$ Except in the narrow circumstances when abstention is appropriate, ${ }^{144}$ the court must at least issue a declaratory judgment determining the state law's constitutionality as applied to the petitioner's intended course of conduct. ${ }^{145}$ When declaratory judgennent is granted in the petitioner's favor, the court inust then determine the probable persuasiveness of its opinion on state officials and courts. If the court feels the declaratory judgment alone will provide the petitioner with sufficient protection that he can exercise his civil hberties without fear that he will be prosecuted for doing so, no additional relief is necessary. If, however, the federal court decides that merely granting declaratory relief will probably not assure state compliance, the court should enjoin enforcement of the statute until the state obtains a permissible narrowing construction through a noncriminal proceeding. ${ }^{146}$

In view of the difficulty that federal courts liave had in predicting whether their decisions will be voluntarily accepted ${ }^{147}$ and the uncertainty concerning the res judicata effect of a federal declaratory judgment that a statute is unconstitutional, ${ }^{148}$ the wiser course is for a federal court always to supplement its declaratory judgment with an injunction unless the state is willing to disavow in court any intent to enforce the statute ${ }^{149}$ or there are unusual circumstances that make the federal injunction particularly intrusive or offensive. ${ }^{150}$ An injunctive order tells the parties precisely what conduct the Constitution demands be allowed to continue unhampered and, through the threat of contempt proceedings, guarantees that the constitutional prescriptions

143. 389 U.S. 241 (1967).

144. See text accompanying notes $43-60$ supra.

145. 389 U.S. at 255.

146. Dombrowski v. Pfister, 380 U.S. 479, 491 (1965); see Zwickler v. Koota, 389 U.S. $241,254-55$ (1967).

If a narrowing construction is obtained, the federal court should allow the statute to be enforced against conduct within the narrow construction, even if the conduct occurred before that construction was obtained-provided this does not deprive the defendants of fair warning. See Younger v. Harris, 401 U.S. 37, 50 (1971); Dombrowski v. Pfister, 381 U.S. $479,491 \&$ n.7 (1965). The fair-notice issue is discussed in Shuttlesworth v. City of Birmingham, 394 U.S. 147, 153-59 (1969).

147. Compare Demich, Inc. v. Ferdon, 426 F.2d 643 (9th Cir. 1970), vacated mem., 401 U.S. 990 (1971) with Monica Theater v. Municipal Ct., 9 Cal. App. 3d 1, 16, 88 Cal. Rptr. 71, 81-82 (2d Dist. 1970).

148. See note 113 supra.

149. Cf. Harrison v. NAACP, 360 U.S. 167, 178-79 (1959) (promise not to prosecute the petitioner pending the final outcone of the suit); Beal v. Missouri Pac. R.R., 312 U.S. 45, 50 (1941) (promise to bring only a single test case); Wells v. Hand, 238 F. Supp. 779, 784 (M.D. Ga.), aff'd mem. sub nom. Wells v. Reynolds, 382 U.S. 39 (1965) (prosecutor disavowed any intent to bring further prosecutions under clearly unconstitutional statutes).

150. See Samuels v. Mackell, 401 U.S. 66, 73 (1971) (dictum). 
will be obeyed..$^{151}$ While coercive orders against state officials should be avoided, this interest is best served by withholding federal court intervention until the reasons for allowing federal action outweigh the reasons for avoiding coercive interference in state criminal inatters. This is done by the Douglas rule and the case-or-controversy constraints. Once a proper case for federal intervention exists, however, nothing is gained by issuing a declaratory judgment and hoping that it will be obeyed, rather than issuing an injunction that must be obeyed..$^{152}$

\section{IV}

\section{The Anti-Injunction Statute}

In addition to the judicially imposed limitations on federal intervention, a coinplete prohibition of injunctions, and perhaps declaratory judgments, ${ }^{153}$ that interfere with state prosecutions pending ${ }^{154}$ at the time federal relief is first sought may be contained in the anti-injunction statute, ${ }^{155}$ which declares:

A Court of the United States may not grant an mjunction to stay proceedings in a State court except as expressly authorized by Act of Congress, or where necessary in aid of its jurisdiction, or to protect or effectuate its judgements.

By its terms the statute prohibits all intervention suits, but in Ex parte Young $^{156}$ the Supreine Court declared that it does not prohibit a federal court froin enjoining the commencement of state criminal proceedings. The Court has also suggested that in civil liberties intervention suits the statute might not prohibit a federal court froin enjoining a pending state prosecution, ${ }^{157}$ but the Court has never decided the point. ${ }^{158}$ Consequently, the lower federal courts, which frequently

151. Cf. Gunn v. University Comm. to End the War in Viet Nam, 399 U.S. 383, $389(1970)$.

152. See Machesky v. Bizzell, 414 F.2d 283, 286 (5th Cir. 1969).

153. If the anti-injunction statute were held to bar injunctive relief in this situation, declaratory relief would probably also be prohibited. See Machesky v. Bizzell, 414 F.2d 283, 286 (5th Cir. 1969); cf. Sanuels v. Mackell, 401 U.S. 66, 69-74 (1971); Great Lakes Dredge \& Deck Co. v. Huffmau, 319 U.S. 293, 298-301 (1943). But see Perez v. Ledesma, 401 U.S. 82, 128-29 n.18 (1971) (Brennan, J., dissenting); Johnson v. Lee, 281 F. Supp. 650, 653 \& n.1 (D. Conn. 1968) (dictum); Ware v. Nichols, 266 F. Supp. 564, 569 (N.D. Miss. 1967).

154. There is some confusion concerning when a state action is pending. See note 109 supra.

155. 28 U.S.C. $\$ 2283(1970)$.

156. 209 U.S. $123,161-62$ (1908).

157. See Dombrowski v. Pfister, 380 U.S. 479,484 n.2 (1965).

158. Although the statute has been referred to in several of the Supreme Court's opinions concerning federal intervention, the Court has never decided whether it is applicable in this situation. In Stefanelli v. Minard, 342 U.S. 117, 120 (1951), the Court cited the statute as one of several evidencing congressional concern about federal inter- 
face this issue, have looked to the legislative history of the statute and to Supreme Court cases applying the statute in other circumstances.

Neither the legislative history nor the Supreme Court cases have given much assistance. The present version of the anti-mjunction statute has only been in effect since 1948, but in a comparable form it has existed since 1793-four years after the federal courts were first established. ${ }^{159}$ It is not known why the statute was originally enacted, ${ }^{100}$ nor is it clear what was intended by the changes made in 1948. The Reviser's Notes ${ }^{101}$ state that the changes were intended to reverse a narrow interpretation given the old version of the statute by the Supreme Court ${ }^{162}$ and to reestablish the prior law. However, nobody has ever been able to understand how the three explicit exceptions put into the 1948 revision were intended to codify numerous judicially created exceptions that had existed, and so the codification has left matters somewhat confused. ${ }^{163}$ This confusion is especially great with regard to federal injunctions staying state criminal actions, because the Reviser's Notes indicate that only applications of the statute to civil actions were considered. ${ }^{104}$ Moreover, the Supreme Court's cases dealing with the statute since its revision have not clarified the confusion that the poor drafting created. In the first major case construing the revised statute, Amalgamated Clothing Workers v. Richman Brothers Co., ${ }^{165}$ the Court declared that since the revised statute is "a clear-cut prohibition qualified only by specifically defined exceptions," no further judicially created exceptions would be allowed. Two years later, however, in Leiter Minerals, Inc. v. United States, ${ }^{160}$ the Court incongruously held that there is at least one nonstatutory ex-

vention, but the case was decided on other grounds. In Dombrowski v. Pfster, 380 U.S. 471, 484 n.2 (1965), the Court considered the anti-injunction statute and determined that it does not prevent a federal court from correcting an erroneous refusal to intervene, even though a state prosecution is commenced in the interim. However, the Court adroitly avoided deciding any more than this narrow point. In Cameron v. Johnson, 390 U.S. 611, 613-14 n.3 (1968), and Younger v. Harris, 401 U.S. 37, 54 (1971), the Court decided the cases on other grounds and explicitly refused to resolve this issue.

159. The provision was originally enacted as the Act of Marcli 2, 1793, ch. 22, $\S 5,1$ Stat. 334. Apart from a minor change in 1875 , the statute relnained unchanged until the most recent codification in 1948. See Wright $\$ 47$, at 177-78 \& nn.2, 4 .

160. See generally Toucey v. New York Life Ins. Co., 314 U.S. 118, 129-32 (1941); Taylor \& Willis, The Power of Federal Courts to Enjoin Proceedings in State Courts, 42 YaLe L.J. 1169, 1170-72 (1933); Warren, Federal and State Court Interference, 43 HARV. L. REv. 345, 347-48 (1930).

161. Reviser's Notes, 28 U.S.C. 2283 (1970) [hereinafter cited as Reviser's Notes].

162. See Toucey v. New York Life Ins. Co., 314 U.S. 118 (1941).

163. See generally WRIGHT $\S 47$, at 179-82; Currie, supra note 80 , at $322-24$.

164. Reviser's Notes.

165. 348 U.S. $511,515-16$ (1955).

166. 352 U.S. 220 (1957). 
ception: the prohibition does not apply when an injunction is sought by the United States. The Court argued that in this situation the federal interests outweighed the principle of coinity that the anti-injunction statute codifies. ${ }^{167}$

The result of the confused legislative history and the Supreme Court's conflicting interpretations is that the lower federal courts have had considerable difficulty determining how the statute applies to federal injunctions staying pending state criminal proceedings. The only uncontroverted point is that a federal court can properly act when the federal government petitions for an injunction. ${ }^{108}$ In other types of cases, courts have relied upon two theories for allowing rehef against a pending prosecution, but eacli has been held to be invalid by other courts. The first, borrowing from the Supreme Court's reasoning in Leiter Minerals, argues that the anti-injunction statute is not an absolute prohibition, but merely a codification of a primciple of comity that may be ignored whenever interests inore important than avoiding conflict with state courts-such as protecting civil liberties from state impingement-are involved. ${ }^{169}$ This rationale had been the one most frequently used to avoid the limitations of the anti-injunction statute, but recently its premise - that the statute is only a principle of comity that may be ignored-was explicitly rejected by the Supreme Court. ${ }^{170}$

The second theory argues that civil liberties intervention suits are "expressly authorized by an Act of Congress,"171 42 U.S.C. § 1983, ${ }^{172}$ and thus are a statutory exception to the anti-injunction statute. Section 1983 authorizes "an action at law, suit in equity, or other proper proceedings for redress" of any deprivation of federal constitutional rights under color of state law. While this obviously does not "expressly" authorize an exception to the anti-injunction statute, courts have declared similarly vague grants to be express exceptions. For example, although it is only by implication that the Securities Exchange Act authorizes private action to redress proxy violations, ${ }^{178}$ one court held that, because granting a private party an injunction to stay a state court proceeding is sometimes necessary to accomplish the purposes of the Act, anti-suit injunctions were "expressly authorized."174

167. Id. at 226 .

168. United States v. Wood, 295 F.2d 772 (5th Cir. 1961), cert. denied, 369 U.S. 850 (1962).

169. E.g., Machesky v. Bizzell, 414 F.2d 283 (5th Cir. 1969); Baines v. City of Danville, 337 F.2d 579, 593 (4th Cir. 1964), cert. denied, 381 U.S. 939 (1965).

170. Atlantic Coast Line R.R. v. Brotherhood of Locomotive Eng'rs, 398 U.S. 281, 286-87 (1970).

171. 28 U.S.C. \$ 2283 (1970).

172. Originally enacted as Act of April 20, 1871, ch. 22, $\$ 1,17$ Stat. 13.

173. See J.I. Case Co. v. Borak, 377 U.S. 426 (1964).

174. Studebaker Corp. v. Gitlin, 360 F.2d 692 (2d Cir. 1966). 
Similarly, it is argued that section 1983, a broad provision for the protection of constitutional rights from state impingements, must be interpreted to authorize enjoining criminal prosecutions, as prosecutions are instruinentalities readily available to state officials intending to deprive citizens of federal liberties. ${ }^{175}$ Thus, several courts have concluded that section 1983 is an express exception to the anti-injunction statute, ${ }^{178}$ but numerous other courts have reached the opposite conclusion. ${ }^{177}$ It is likely that when the Supreme Court finally resolves this conflict it will hold that section 1983 is not an "expressly authorized" exception. The Court has recently restated its position that exceptions to the anti-injunction statute should be narrowly construed, rather than enlarged by loose statutory construction,; ${ }^{178}$ holding section 1983 to be an express exception violates this principle. Furthernore, in both of its major decisions demanding a strict construction of the current version of the anti-injunction statute, ${ }^{179}$ the Court's concern has been that, unless the statute is strictly construed, lower federal courts would use their power to stay state court proceedings so as to exercise quasi-appellate review of the state courts; holding that section 1983 is an express exception risks this type of quasi-appellate review. ${ }^{180}$

175. See Sheridan v. Garrison, 415 F.2d 699, 706 (5th Cir.), cert. denied, 396 U.S. 1040 (1969). See also Younger v. Harris, 401 U.S. 37, $61-63$ (1971) (Douglas, J., dissenting).

176. E.g., Sheridan v. Garrison, 415 F.2d 699, 704-05 (5th Cir.), cert. denied, 396 U.S. 1040 (1969); Cooper v. Hutchinson, 184 F.2d 119, 124 (3d Cir. 1950); Grove Press, Inc. v. City of Philadelphia, 300 F. Supp. 281, 288 (E.D. Pa.), modified, 418 F.2d 82 (3d Cir. 1969); Landry v. Daley, 288 F. Supp. 200, 223 (N.D. Ill.), appeal dismissed, 393 U.S. 220 (1968), rev'd sub nom. Boyle v. Landry, 422 F.2d 631 (7th Cir. 1970); Matzner v. Brown, 288 F. Supp. 608, 610-11 (D.N.J. 1968); Hooper v. Gooding, 282 F. Supp. 624, 627 (D. Ariz.), rev'd on other grounds per curiam, 394 F.2d 146 (9th Cir. 1968), cert. denied, 391 U.S. 917 (1968).

177. E.g., Baines v. City of Danville, 337 F.2d 579, 588-93 (4th Cir. 1964), cert. denied, 381 U.S. 939 (1965); Smith v. Village of Lansing, 241 F.2d 856, 859 (7th Cir. 1957).

178. Atlantic Coast Line R.R. v. Brotherhood of Locomotive Eng'rs, 398 U.S. 281, 287 (1970).

179. Atlantic Coast Line R.R. v. Brotherhood of Locomotive Eng'rs, 398 U.S. 281 (1970); Amalgainated Clothing Workers v. Richman Bros. Co., 348 U.S. 511 (1955). In both cases the lower federal court had enjoined enforcement of state court injunctions prohibiting picketing on the basis that the state court decisions were wrong. Each time, the Supreme Court declared that this is an impermissible alteration of the traditional duality of the federal and state court systems; the state imjunctions must be attacked through direct appeal, not through a collateral federal suit. 398 U.S. at 282-87; 348 U.S. at 516-19.

180. See, e.g., Machesky v. Bizzell, 414 F.2d 283 (5th Cir. 1969) (federal court examined a state court injunction regulating civil rights picketing, found it to be impermissibly broad, and therefore enjoined enforcement of the state injunction). See also Baines v. City of Danville, 337 F.2d 579, 589 (4th Cir. 1964), cert. denied, 381 U.S. 939 (1965) (arguing that if section 1983 is an "expressly authorized" ex- 
The Supreme Court is much more likely to accept a theory that creates a narrower exception to the anti-mjunction statute-one that permits only actions staying state criminal matters. ${ }^{181}$ In these cases the Douglas rule-that federal relief staying a pending state action may be granted only if defense of the criminal prosecution would not protect the defendant's civil liberties from irreparable imjury-assures that there will be no alteration of the traditional duality of the federal and state court systems, because a federal court can intervene only if it is necessary to protect interests entirely different from those concerning the state court. Thus, no quasi-appellate control will result. Unfortunately, lowever, no theory that would justify excepting solely criminal intervention cases from the anti-injunction statute has ever been propounded. ${ }^{182}$

\section{CONCLUSION}

The intervention doctrine that remains following the Younger series of cases is a conservative one that allows federal court interference in state criminal matters only when the state criminal courts are legally powerless to protect constitutional rights. Thus, if bad-faith harassment is involved, federal courts can intervene both to enjoin the enforcement of vague or overbroad statutes used to harass the federal petitioners and-unless the Court later concludes that the anti-injunction statute prevents it - to enjoin the continuation of state prosecutions pending against the petitioners. However, absent bad-faith harassment or other as-yet-unexplained "extraordinary circumstances," a federal court cannot intervene in a pending prosecution. This rule applies whether the federal petitioners seek injunctive or declaratory relief, and regardless of whether the petitioners wish to challenge an incidental matter involved in the state prosecution or the entire prosecution. Furthermore, the Younger opinion suggests that the then-majority of the Court

ception, so is every statute providing for equitable relief, and the anti-injunction statute is thus a nullity).

181. See WRIGHT § 52, at 207-08.

182. Witlout doing any violence to the legislative history of the anti-injunction statute, it could be argued that Congress never meant for it to apply to criminal intervention cases. Until Ex parte Young, 209 U.S. 123 (1908), was decided, federal suits interfering in state criminal matters were thought to be barred by the common law rule that equity cannot interfere in criminal proceedings. See, e.g., In re Sawyer, 124 U.S. 200, 210 (1888). It is therefore anachronistic to suppose that when the anti-injunction statute was first enacted in 1793 Congress intended to legislate about criminal intervention suits. Even when Congress amended the statute in 1948, there is no reason to believe that it meant to prevent injunctions staying criminal prosecutions; the failure of the Reviser's Notes even to mention criminal proceedings implies that the issue of intervention in pending prosecutions was entirely ignored. $C f$. Leiter Minerals, Inc. v. United States, 352 U.S. 220, 224-26 (1957). 
would have held that absent extraordinary circumstances intervention is improper even if no state prosecution is pending, but this issue was left for later decisions.

Lynn H. Pasahow 